\title{
Effect of Growth Temperature on Cold Osmotic Shock in Escherichia coli ML 30
}

\author{
By J. W. PATCHING AND A. H. ROSE \\ Microbiology Laboratories, School of Biological Sciences, Bath University, Bath
}

(Accepted for publication 23 September 197I)

Several types of micro-organism, including Gram-negative bacteria (Heppel, 1967), fungi (Wiley, 1970) and yeast (Patching \& Rose, I97I) are susceptible to cold osmotic shock. This is the name given to a procedure which involves suspending organisms in a hyperosmolar solution of a metabolically inert solute containing EDTA, and then in a dilute solution of $\mathrm{MgCl}_{2}$ at $0^{\circ}$. Susceptible organisms then lose their ability to accumulate extracellular solutes but retain their viability (Heppel, 1967). Cold osmotic shock releases solute-binding proteins (Heppel, 1967; Wiley, 1970) and the technique is now widely used to extract these proteins from micro-organisms (Kaback, 1970). However, almost nothing is known of the physiological basis of cold osmotic shock and in particular of the role of the osmotic-, temperatureand EDTA-induced stresses which are involved.

The effects of cold stress may arise from the freezing of membrane lipids which facilitates release of membrane-bound transport proteins. Freezing of membrane lipids is thought to be important in the related phenomenon of cold shock in Gram-negative bacteria (Farrell \& Rose, 1968). A decrease in growth temperature leads to synthesis of an increased proportion of unsaturated fatty-acid residues in microbial lipids (Farrell \& Rose, 1967), which results in a lowering of the melting point of the lipids (Chapman, 1967). Such a lowering can be significant with only a few per cent increase in unsaturation (Lyons \& Asmundson, 1965). This report shows that Escherichia coli growing at $15^{\circ}$ rather than $37^{\circ}$ synthesizes more unsaturated lipids, but this does not remove the susceptibility of the bacteria to cold osmotic shock, although organisms grown at the two temperatures respond to it differently.

\section{METHODS}

The strain of Escherichia coli ML 30 used was provided by Dr J. L. Ingraham of the Department of Bacteriology, University of California, Davis, California, U.S.A. The bacterium was grown at $37^{\circ}$ or $15^{\circ}$ in 11 . batches of medium containing (per 1.): glucose (2 g.), $\mathrm{KH}_{2} \mathrm{PO}_{4}$ (3 g.), $\mathrm{K}_{2} \mathrm{HPO}_{4}\left(7 \mathrm{~g}\right.$.), $\left(\mathrm{NH}_{4}\right)_{2} \mathrm{SO}_{4}\left(5 \mathrm{~g}\right.$.), and $\mathrm{MgSO}_{4} .7 \mathrm{H}_{2} \mathrm{O}$ (0.5 g.); pH 7. I. Cultures were incubated as described by Patching \& Rose (1969). Organisms were harvested from logarithmic-phase cultures containing $0.05 \mathrm{mg}$. dry wt organisms $/ \mathrm{ml}$. They were washed once with phosphate buffer $\left(\mathrm{pH} 7.0 ; 37^{\circ}\right)$ and either used immediately in cold osmotic shock experiments or, after washing twice with cold $\left(4^{\circ}\right)$ water, freeze-dried prior to lipid extraction.

The complete cold osmotic shock treatment involved suspending organisms to a concentration of $0.5 \mathrm{mg}$. dry $\mathrm{wt} / \mathrm{ml}$. at $37^{\circ}$ in tris buffer $(\mathrm{pH} 7.2)$ containing sucrose $(0.5 \mathrm{M})$ and EDTA ( $0.1 \mathrm{mM})$ (stage A). Immediately after suspension, the organisms were removed by centrifugation and suspended to the same concentration in cold $\left(0^{\circ}\right) \mathrm{MgCl}_{2}(0.5 \mathrm{mM})$ (stage B). Modifications to the complete cold osmotic shock treatment are described in the text. Rates of accumulation of the nonmetabolizable sugar $\alpha$-methylglucoside were measured 
by suspending organisms in $0.1 \mathrm{M}-$ phosphate buffer $\left(\mathrm{pH} 7 \cdot 0\right.$ ) containing $10 \mathrm{mM}\left[\mathrm{I}^{-12} \mathrm{C}\right]-\alpha-$ methylglucoside and $\left[{ }^{1-14} \mathrm{C}\right]-\alpha$-methylglucoside to give a final activity of about $3.5 \times 10^{4}$ counts $/ \mathrm{min} / \mu$ mole (Farrell \& Rose, 1971). Rates of accumulation were calculated from the regression coefficients of the time-course plots for accumulation, and are quoted as $\mu$ moles $\alpha$-methylglucoside accumulated/g. dry wt organism/h. Lipids were extracted from freezedried organisms with a mixture of $\mathrm{CHCl}_{3}$ and $\mathrm{CH}_{3} \mathrm{OH}$ (2: I, by vol.); the extract was washed using the procedure of Folch, Lees \& Sloane-Stanley (1957). Lipid contents of organisms were estimated gravimetrically using the method of Rouser, Kritchevsky \& Yamamoto (1967), and phosphorus contents of lipid extracts by the method of Bartlett (1959). Separations of phospholipids by thin-layer chromatography and of fatty-acid methyl esters by gas chromatography were carried out as described by Hunter \& Rose (1972).

\section{RESULTS}

Organisms grown at $15^{\circ}$ contained slightly more lipid (8.9\% dry wt) than those grown at $37^{\circ}(8 \cdot 1 \%)$. Lipids extracted from organisms grown at either temperature contained the same amount $(6.5 \%$ of dry wt) and types of phospholipids in about the same proportions. When the growth temperature was lowered from $37^{\circ}$ to $15^{\circ}$, the major change in the fattyacid composition of the lipids was an increase from $23 \%$ to $36 \%$ in the proportion of $\mathrm{C}_{18: 1}$ and a corresponding decrease in the proportion of $\mathrm{C}_{16: 0}$ acids.

Table I shows the effects of full and modified cold osmotic shock treatments on the ability of bacteria grown at $37^{\circ}$ or $15^{\circ}$ to accumulate $\alpha$-methylglucoside. Rates of accumulation were about the same by untreated organisms grown at $37^{\circ}$ or $15^{\circ}$. The full cold osmotic shock treatment or treatment omitting tris from the solution used in stage A eliminated accumulation in organisms grown at either temperature. Organisms grown at $37^{\circ}$ or $15^{\circ}$ retained their $\alpha$-methylglucoside-accumulating ability when the $\mathrm{MgCl}_{2}$ solution in stage $\mathrm{B}$ was used at $37^{\circ}$ rather than $0^{\circ}$. Only organisms grown at $15^{\circ}$ retained any accumulating ability if EDTA was omitted from stage $A$.

Table I. Effect of full and modified cold osmotic shock treatments on rates of accumulation of $\alpha$-methylglucoside by Escherichia coli ML 30

\begin{tabular}{|c|c|c|c|c|c|c|c|}
\hline \multicolumn{3}{|c|}{$\begin{array}{l}\text { Composition of suspending } \\
\text { liquid in stage } \mathbf{A}\end{array}$} & \multicolumn{2}{|c|}{$\begin{array}{l}\text { Composition of } \\
\text { suspending liquid } \\
\text { in stage B }\end{array}$} & \multirow{2}{*}{$\begin{array}{l}\text { Temperature } \\
\text { of suspension } \\
\text { in stage } B \\
\left({ }^{\circ} \mathrm{C}\right)\end{array}$} & \multicolumn{2}{|c|}{$\begin{array}{c}\text { Rate of accumulation o } \\
\alpha \text {-methylglucoside by } \\
\text { bacteria grown at }\end{array}$} \\
\hline $\begin{array}{l}\text { Sucrose } \\
(0.5 \mathrm{M})\end{array}$ & $\begin{array}{c}\text { EDTA } \\
(0 \cdot 1 \mathrm{mM})\end{array}$ & $\begin{array}{l}\text { Tris buffer } \\
(\mathrm{pH} 7 \cdot 2)\end{array}$ & $\begin{array}{c}\mathrm{MgCl}_{2} \\
(0.5 \mathrm{mM})\end{array}$ & $\begin{array}{c}\text { Sucrose } \\
(0.5 \mathrm{M})\end{array}$ & & $37^{\circ}$ & $15^{\circ}$ \\
\hline- & - & - & - & - & - & 0.109 & 0.104 \\
\hline+ & + & + & + & - & o & 0.00 & 0.00 \\
\hline+ & + & + & + & - & 37 & 0.148 & O.II 8 \\
\hline+ & - & + & + & - & 0 & 0.00 & 0.088 \\
\hline+ & + & + & + & + & 0 & 0.142 & 0.00 \\
\hline- & + & + & + & - & 0 & 0.113 & 0.00 \\
\hline+ & + & - & + & - & 0 & 0.00 & 0.00 \\
\hline
\end{tabular}

When sucrose $(0.5 \mathrm{M})$ was used in both stages $\mathrm{A}$ and $\mathrm{B}$, or in neither stage, only organisms grown at $37^{\circ}$ retained accumulating ability. Omitting tris from the solution used in stage $\mathrm{A}$ did not prevent the loss of solute-accumulating ability by bacteria grown at $37^{\circ}$ or $15^{\circ}$. 


\section{DISCUSSION}

The lowering of the melting point of membrane lipids caused by the increased synthesis of unsaturated fatty acids does not prevent the loss of ability to accumulate $\alpha$-methylglucoside by Escherichia coli subjected to cold osmotic shock. Nevertheless, a cold stress seems to be essential in order to remove solute-transporting ability, as shown by the retention of this ability when the $\mathrm{MgCl}_{2}$ solution in stage B was used at $37^{\circ}$ rather than $0^{\circ}$. The most interesting finding from the data reported concerns the differences shown between organisms grown at $37^{\circ}$ and $15^{\circ}$ in their response to exposure to EDTA in stage A and to the osmotic stress imposed when organisms are transferred from stage A to stage B. Omitting EDTA from the solution used in stage $A$ had no effect on the loss of $\alpha$-methylglucoside-accumulating ability by organisms grown at $37^{\circ}$ whereas it led to the retention of solute-accumulating ability by organisms grown at $15^{\circ}$. Since bacteria grown at either $37^{\circ}$ or $15^{\circ}$ contained the same amounts and types of phospholipid, the need for EDTA treatment by organisms grown at the lower temperature cannot be explained by a greater cation-binding capacity of the membrane lipids. Also the greater degree of unsaturation in the lipids in membranes of bacteria grown at $15^{\circ}$ may lead to a less avid binding of divalent ions (Shah \& Schulman, 1965), which would lessen rather than increase the need for EDTA treatment in order to affect membrane structure. The need by organisms grown at $37^{\circ}$, but not those grown at $15^{\circ}$, for an osmotic stress between stages A and B might be related to the greater mobility of the more unsaturated lipids in bacteria grown at the lower temperature, an explanation which was invoked to explain a greater rate of solute permeation in liposomes prepared from lipids of $E$. coli grown at low as compared with high temperatures (Haest, de Gier \& Van Deenen, 1969). Our data suggest therefore that the loss of membrane-bound transport proteins when $E$. coli is subjected to cold osmotic shock is probably not due simply to the freezing of membrane lipids, although the degree of unsaturation in the membrane lipids may influence the response of bacteria to both the EDTA-induced and osmotic stresses involved in cold osmotic shock.

We are grateful to the Science Research Council (U.K.) for a grant (B/SR/5724) in support of this work, and to Mr K. Hunter of this Laboratory for assistance in the lipid analyses. J. W. P. also thanks the Science Research Council (U.K.) for the award of a research studentship.

\section{REFERENCES}

BARtlett, G. R. (1959). Phosphorus assay in column chromatography. Journal of Biological Chemistry 234 , $466-468$.

Chapman, D. (1967). The effect of heat on membrane constituents. In Thermobiology, pp. 123-146. Edited by A. H. Rose. London: Academic Press.

FARRell, J. \& Rose, A. H. (1967). Temperature effects on micro-organisms. In Thermobiology, pp. 147-218. Edited by A. H. Rose. London: Academic Press.

FARRell, J. \& Rose, A. H. (1968). Cold shock in mesophilic and psychrophilic pseudomonads. Journal of General Microbiology 50, 429-439.

FARRELl, J. \& Rose, A. H. (197I). Temperature effects on solute accumulation by Candida utilis. Archiv für Mikrobiologie 79, $122-139$.

Folch, J., Lees, M. \& Sloane-Stanley, G. H. (1957). A simple method for the isolation and purification of total lipids from animal tissues. Journal of Biological Chemistry 226, 497-509.

HAest, C. W. M., DE GieR, J. \& VAN DEEnEN, L. L. M. (1969). Changes in the chemical and barrier properties of the membrane lipids of Escherichia coli by variations in the temperature of growth. Chemistry and Physics of Lipids 3, 413-417.

Heppel, L. A. (1967). Selective release of enzymes from bacteria. Science, New York 156, I45I-I455. 
HuNTER, K. \& Rose, A. H. (1972). Lipid composition of Saccharomyces cerevisiae as influenced by growth temperature. Biochimica et biophysica acta (in the Press).

KABACK, H. R. (1970). Transport. Annual Review of Biochemistry 39, 56I-598.

Lyons, J. M. \& ASMUNDson, C. M. (1965). Solidification of unsaturated/saturated fatty acid mixtures and its relationship to chilling sensitivity in plants. Journal of the American Oil Chemists Society 42, 10561058.

Patching, J. W. \& Rose, A. H. (1969). The effects and control of temperature. In Methods in Microbiology, vol. 2, pp. 23-38. Edited by J. R. Norris and D. W. Ribbons. London: Academic Press.

Patching, J. W. \& Rose, A. H. (I97I). Cold osmotic shock in Saccharomyces cerevisiae. Journal of Bacterio$\log y$ 108, 45I-459.

Rouser, G., KRITChevsky, G. \& YAMAMOTo, A. (1967). Column chromatographic and associated procedures for separation and determination of phosphatides and glycolipids. In Lipid Chromatographic Analysis, vol. I, p. I08. Edited by G. V. Marinetti. London: Edward Arnold.

ShaH, D. O. \& Schulman, J. H. (1965). Binding of metal ions to monolayers of lecithins, plasmalogens, cardiolipin, and dicetyl phosphate. Journal of Lipid Research 6, 34I-349.

WILEY, W. R. (1970). Tryptophan transport in Neurospora crassa: a tryptophan-binding protein released by cold osmotic shock. Journal of Bacteriology 103, 565-662. 